\title{
Locomotor Deficiencies and Aberrant Development of Subtype-Specific GABAergic Interneurons Caused by an Unliganded Thyroid Hormone Receptor $\alpha 1$
}

\author{
Karin Wallis, ${ }^{1 \star}$ Maria Sjögren, ${ }^{1 \star}$ Max van Hogerlinden, ${ }^{1}$ Gilad Silberberg, ${ }^{2}$ André Fisahn, ${ }^{2}$ Kristina Nordström, ${ }^{1}$ \\ Lars Larsson, ${ }^{4}$ Håkan Westerblad, ${ }^{3}$ Gabriela Morreale de Escobar, ${ }^{5}$ Oleg Shupliakov, ${ }^{2}$ and Björn Vennström ${ }^{1}$ \\ Departments of ${ }^{1} \mathrm{Cell}$ and Molecular Biology, ${ }^{2}$ Neuroscience, and ${ }^{3}$ Physiology and Pharmacology, Karolinska Institutet, SE-171 77 Stockholm, Sweden, \\ ${ }^{4}$ Department of Neuroscience, Uppsala University, SE-751 24 Uppsala, Sweden, and 5Instituto de Investigaciones Biomédicas “Alberto Sols," Consejo \\ Superior de Investigaciones Científicas-Universidad Autónoma de Madrid and Center for Biomedical Research on Rare Diseases, 28029 Madrid, Spain
}

Thyroid hormone (TH) deficiency during development causes severe and permanent neuronal damage, but the primary insult at the tissue level has remained unsolved. We have defined locomotor deficiencies in mice caused by a mutant thyroid hormone receptor $\alpha 1$ $(\mathrm{TR} \alpha 1)$ with potent aporeceptor activity attributable to reduced affinity to TH. This allowed identification of distinct functions that required either maternal supply of TH during early embryonic development or sufficient innate levels of hormone during late fetal development. In both instances, continued exposure to high levels of TH after birth and throughout life was needed. The hormonal dependencies correlated with severely delayed appearance of parvalbumin-immunoreactive GABAergic interneurons and increased numbers of calretinin-immunoreactive cells in the neocortex. This resulted in reduced numbers of fast spiking interneurons and defects in cortical network activity. The identification of locomotor deficiencies caused by insufficient supply of TH during fetal/perinatal development and their correlation with subtype-specific interneurons suggest a previously unknown basis for the neuronal consequences of endemic cretinism and untreated congenital hypothyroidism, and specifies TR $\alpha 1$ as the receptor isoform mediating these effects.

Key words: thyroid hormone receptor; parvalbumin; calretinin; GABA; hypothyroid; interneuron; locomotion

\section{Introduction}

Thyroid hormone (TH) plays a pivotal role in development. This is manifested in endemic cretinism and congenital hypothyroidism, which both lead to irreversible mental retardation and motor dysfunctions (Delange, 1996; DeLong, 1996). Endemic cretinism is the result of insufficient supply of TH to the fetus and is caused by severe iodine deficiency in the pregnant woman, whereas congenital hypothyroidism is caused by later events of impaired TH synthesis in the fetus or newborn. Although the neurological manifestations of these syndromes have been known for decades, the primary insults at the tissue level have remained unclear.

The effects of TH are mediated by the distinct nuclear thyroid hormone receptors (TRs) TR $\alpha 1$ and TR $\beta$ that act as ligand modulated transcription factors. Target genes activated by $\mathrm{TH}$ are

\footnotetext{
Received Sept. 4, 2007; revised Jan. 6, 2008; accepted Jan. 6, 2008.

This work was supported by the Swedish Cancer Society, the Swedish Research Council, and The Wallenberg foundations. We thank Drs. Douglas Forrest, Juan Bernal, and Ola Hermanson for constructive criticism on this manuscript, and Dr. Barbara Canlon for use of the CAST-GRID software for cell quantification.

*K.W. and M.S. contributed equally to this work.

Correspondence should be addressed to Prof. Björn Vennström, Department of Cell and Molecular Biology, Medical Nobel Institute, Karolinska Institutet, Box 285, SE-171 77 Stockholm, Sweden. E-mail: bjorn.vennstrom@ki.se.

DOI:10.1523/JNEUROSCI.5163-07.2008

Copyright $\odot 2008$ Society for Neuroscience $\quad$ 0270-6474/08/281904-12\$15.00/0
}

often transcriptionally strongly suppressed by an unliganded TR (i.e., aporeceptor), whereas genes that are downregulated by ligand, such as the TSH $\beta$ gene, are thought to be activated by the aporeceptor. The TR $\alpha 1$ isoform has been ascribed a prominent role in brain development and function because it accounts for $70-80 \%$ of total TR expression in the brain (Schwartz et al., 1992). Several broad effects of hypothyroidism have been reported: diminished myelination, reduced arborization, and migration defects (Bernal et al., 2003).

Interneurons containing the inhibitory neurotransmitter GABA modulate somatic output of cortical networks through their direct inhibitory effects on excitatory neurons. This highly heterogenous cell type can be classified according to their morphology, electrophysiology and neurochemical phenotype (Markram et al., 2004). Antibodies against the calcium-binding proteins parvalbumin $(\mathrm{PV})$, calbindin $(\mathrm{CB})$, calretinin $(\mathrm{CR})$, and the neurohormone somatostatin (SOM) are commonly used to distinguish subtypes of interneurons (Kawaguchi and Kubota, 1997). Parvalbumin-immunoreactivity is present in a subpopulation of GABAergic neurons that have a fast spiking (FS) firing pattern. Reduced immunostaining indicates presence of fewer cells, impaired axonal development or reduced arborization.

Previously, we studied mice expressing a dominant-negative point mutation (R384C) in the TR $\alpha 1$ gene (Tinnikov et al., 2002). The mutant receptor has a 10 -fold lower affinity to $\mathrm{TH}$ and 
thus acts as an aporeceptor. The mutation induces a receptormediated hypothyroidism in the tissues in which it is expressed, including the brain. The heterozygous animals, "TR $\alpha 1+/ m$ " mice, exhibit anxiety and memory deficiencies (Venero et al., 2005). Here, we have identified locomotor disabilities caused by the TR $\alpha 1 \mathrm{R} 384 \mathrm{C}$ aporeceptor that manifest in the adult mouse, but are founded during fetal/perinatal development. These were similar to the type of insults seen in endemic cretinism and could be ameliorated by treatment with pharmacological doses of $\mathrm{TH}$ during specific stages of prenatal and postnatal development. The time at which the reversal of the aporeceptor activity was achieved correlated with when aberrant differentiation of PVand CR-immunoreactive (IR) interneurons were seen in development of the neocortex. Furthermore, electrophysiological analyses identified perturbed neuronal connectivity. Both types of GABAergic interneurons have critical roles in the control of locomotor activity, and their identification as specific targets for $\mathrm{TH}$ action leads to new understanding of the consequences of hypothyroidism during fetal/perinatal stages for correct brain development.

\section{Materials and Methods}

Animals. The mouse strain carrying the dominant-negative R384C mutation in TR $\alpha 1$ and the combination with a TR $\beta$ null allele have been described previously (Tinnikov et al., 2002). The TR $\alpha 1$ R384C mice used in the experiments here had been backcrossed to C57BL/6NCrl for 3-10 generations. Experiments done in all cohorts produced similar results. Littermate males heterozygous for the mutant allele ( $T R \alpha 1+/ m$ mice) and wild-type (wt) mice were kept at $21^{\circ} \mathrm{C}$ on a $12 \mathrm{~h}$ light/dark cycle. For all behavioral tests, before testing, animals aged 4-7 months were brought to the experimental room for $60 \mathrm{~min}$ and handled daily during $3 \mathrm{~d}$ before the experiment to allow habituation to experimental manipulations. The experiments were done between 12:00 and 6:00 P.M. Animal care procedures were in accordance with the guidelines set by the European Community Council Directives (86/609/EEC). Required animal permissions were obtained from the local ethical committees. The TH treatments were done as described previously (Venero et al., 2005)

SHIRPA. The SHIRPA primary screen (Rogers et al., 1997) was used to assess the behavioral and functional profile of the $T R \alpha 1+/ m$ mice. A clear Perspex cylinder with a $14 \mathrm{~cm}$ diameter and $18 \mathrm{~cm}$ height placed on tripod of $10 \mathrm{~cm}$ height was used for evaluation of undisturbed behavior for $5 \mathrm{~min}$. Subsequently, the mouse was transferred to an arena $(54 \times 32$ $\mathrm{cm}$ ) for observation of motor behavior. Afterward, a sequence of manipulations using tail suspension and supine restraint was performed to evaluate parameters such as grip strength, limb tone, and reflexes. The procedure was ended by the measurement of body weight. The equipment was cleaned with $70 \%$ ethanol between animals. Scoring was performed as proposed by Hatcher et al. (2001) with some modifications as suggested by the Standard Operating Procedures in Eumorphia EMPReSS (http://empress.har.mrc.ac.uk/). Respiration, heart rate, salivation, fear, irritability, and body temperature were not assessed.

Hanging wire. Mice were placed on the top of a wire cage lid which was held above the cage litter at a height high enough to prevent the mice from easily climbing down but not high enough to cause harm in the event of a fall. The lid was then turned upside down and the latency to fall off the wire lid was observed. To score positive in the test, the mice had to cling to the grid for $60 \mathrm{~s}$.

Grip strength. Muscle strength of mutant and wt mice was determined by the use of an automated grip strength meter (TSE Systems, Bad Homburg, Germany). Grip strengths of forelimbs and hindlimbs were determined separately. Mice were placed on a platform, allowed to grasp a ring with either forelimbs or hindlimbs, and then steadily pulled away until the grip was broken. Grip strength was determined with a computerized electronic pull strain gauge that was fitted directly to the grasping ring. Individual animals were exposed to three successive repeated and recorded measurements.

Beam walk. The beam walk test was performed as described by Carter et al. (2001). Briefly, the mice were trained for 3 consecutive days to cross a series of elevated, narrow beams to reach an enclosed escape platform. The beams used in the experimental setup were square beams, 21 and 12 $\mathrm{mm}$ wide, and round beams, 21 and $15 \mathrm{~mm}$ wide. Each daily trial consisted of four complete crossings on the $21 \mathrm{~mm}$ wide square beam and for each crossing, the traversing time and the number of times the right and left hindlimbs slipped were recorded. On the day of testing, two trials for each beam were performed and the mean scores for each measure were then used in the analysis.

Footprint analysis. Mice were trained to walk on filter paper along a runway ( $80 \mathrm{~cm}$ long, $8 \mathrm{~cm}$ wide) the day before the test. For the test, blue and green nontoxic paint were applied to the hind and fore paws, respectively. The resulting footprint traces were then analyzed, measuring five parameters: (1) stride length for forelimbs and hindlimbs, determined by measuring the average distance of forward movement between each stride; (2) front and hind base width by measuring the distance between the right and left hind paws (hind base) and the right and left front paws (front base); (3) interstep distance by measuring the distance between steps for both forelimbs and hindlimbs; (4) heel usage by counting the number of times the mice walked on their heels during 10 steps; and (5) hind paw angle by measuring the relative angle between the respective outermost digits during forward movement. Footprint parameters were determined by drawing parallel lines through the center of each footprint and measuring the distance (in centimeters) between the appropriate lines.

Hormone assays. Serum total T4 levels were determined with a radioimmunoassay kit (Diagnostic Products, Los Angeles, CA). Cerebellar tissue T3 and T4 levels were determined as described previously (Escobar-Morreale et al., 1996).

Muscle physiology test. Intact fast-twitch extensor digitorum longus (EDL) and slow-twitch soleus muscles from adult mutant and wt mice were assessed for contractile function as described previously (Johansson et al., 2000), with minor modifications.

Determination of myosin heavy chain isoform composition. The myosin heavy chain composition of EDL and soleus muscles of adult mutant and wt mice was determined by SDS-PAGE as described previously (Yu et al., 2000).

Whole mount muscle staining. Pregnant dams were killed at E18.5 with $\mathrm{CO}_{2}$ and the embryos were subsequently dissected in cold PBS and decapitated. Hindlimbs were removed of skin and fixated in $4 \%$ paraformaldehyde in $0.1 \mathrm{M}$ phosphate buffer (PB) for $1 \mathrm{~h}$ on ice and washed in PBS followed by inactivation in $0.1 \mathrm{M}$ glycine for $2 \mathrm{~h}$ at room temperature. Muscles were then incubated in blocking solution containing 4\% BSA and $0.5 \%$ Triton X-100 in PBS for $24 \mathrm{~h}$. This was followed by double labeling with rabbit anti-neurofilament 150 (1:2000; Millipore, Hampshire, UK; AB1981) and $1 \mu \mathrm{g} / \mathrm{ml}$ Alexa Flour 488-conjugated bungarotoxin (Invitrogen, Stockholm, Sweden; B13422) in blocking solution overnight at $4^{\circ} \mathrm{C}$ and then washed for several hours on a shaking device. Muscles were subsequently incubated with $\mathrm{Cy} 3$ conjugated anti-rabbit IgG (1:1000; Jackson ImmunoResearch, West Grove, PA; 711-165-152) overnight at $4^{\circ} \mathrm{C}$ and washed. Muscles were mounted in Mowiol (Sigma, Stockholm, Sweden) and stored at $-20^{\circ} \mathrm{C}$. A Zeiss (Oberkochen, Germany) confocal microscope (LSM510 Meta) was used for examination.

Toluidine staining of semithin sections. Adult mice were anesthetized by intraperitoneal injection of Avertin $(0.15 \mu \mathrm{l} / \mathrm{g}$ body weight of $2.5 \%$ solution in PBS) and perfused transcardially with warm PBS followed by a mixture of $3 \%$ glutaraldehyde and $0.5 \%$ paraformaldehyde in PBS. The lumbar region of the spinal cord and the sciatic nerve were dissected out and postfixed for $4 \mathrm{~h}$. The tissues were then washed in PBS overnight at $4^{\circ} \mathrm{C}$. The dorsal and ventral roots were cut and incubated with the sciatic nerve in $1 \%$ osmium tetraoxide followed by embedding in Durcapan ACM (Fluka, Saint Quentin Fallavier, France). Transverse $0.5 \mu \mathrm{m}$ sections were stained with toluidine blue and examined by light microscopy.

Immunohistochemistry. Mice were anesthetized by intraperitoneal injection of Avertin. The mice were perfused transcardially with warm PBS followed by cold $4 \%$ paraformaldehyde in $0.1 \mathrm{M} \mathrm{PB}$ at $\mathrm{pH}$ 7.4. The brains were removed and postfixed in perfusion solution overnight at $4^{\circ} \mathrm{C}$ and subsequently cryoprotected in $30 \%$ sucrose in PBS and frozen at $-70^{\circ} \mathrm{C}$. Immunohistochemistry was performed on free-floating $25 \mu \mathrm{m}$ cryostat 
coronal sections of the cerebral cortex or sagittal cerebellar sections. The sections were treated with $1 \% \mathrm{H}_{2} \mathrm{O}_{2}$ in PBS to remove endogenous peroxidase activity and blocked with $5 \%$ normal goat serum (NGS), avidin (Vector Laboratories, Peterborough, UK; SP-2001), and 0.3\% Triton $\mathrm{X}-100$ in PBS for $1 \mathrm{~h}$. In some cases (anti-GAD1, anti-SOM) the blocking steps were performed after incubation of sections in Na-citrate $(10 \mathrm{~mm})$ at $90^{\circ} \mathrm{C}$ for $30 \mathrm{~min}$ for antigen retrieval. After blocking the sections were incubated with primary antibody in $2.5 \% \mathrm{NGS}$, biotin (Vector Laboratories; SP-2001), and $0.3 \%$ Triton X-100 in PBS overnight at $4^{\circ} \mathrm{C}$. Primary antibodies used were as follows: rabbit anti-PV (1:10000; Swant, Bellizona, Switzerland; PV-28), rabbit anti-CR (1:5000; Swant; 7699/4), rabbit anti-SOM (1:500; Millipore; AB5494), goat anti-human GAD1 [1:1000; $67 \mathrm{kDa}$ glutamate decarboxylase (GAD67); R \& D Systems, Abingdon, UK; AF2086], mouse anti-NeuN (1:500; Millipore; MAB377), rabbit anti-CB (1:10000; Swant; CB-38a). For anti-GAD1 a different blocking solution was used: 5\% normal horse serum, 2\% BSA, avidin/biotin, and $0.1 \%$ Tween 20 in $0.1 \mathrm{M}$ TBS. The sections were subsequently washed in $0.1 \%$ Triton X-100 in PBS and incubated in speciesspecific biotinylated secondary antibodies $(1: 250)$ for $1 \mathrm{~h}$ room temperature (Vector Laboratories; BA-1000, BA-2000, BA-9500) followed by $\mathrm{ABC}$ kit (Vector Laboratories; PK-6100) and visualization with 0.5 $\mathrm{mg} / \mathrm{ml}$ diaminobenzidine and $0.01 \% \mathrm{H}_{2} \mathrm{O}_{2}$. Sections were mounted on glass slides, dried for $2 \mathrm{~h}$ at $37^{\circ} \mathrm{C}$ and subsequently dehydrated, cleared in xylene, and coverslipped.

Whole-cell patch-clamp recordings. Parasagittal slices (300 $\mu \mathrm{m}$ thick) were obtained from three wt and three mutant mice [postnatal day 19 (P19)-P21]. Slices were cut in ice-cold extracellular solution and then kept in $33-35^{\circ} \mathrm{C}$ for at least $30 \mathrm{~min}$, and then moved to room temperature $\left(20-22^{\circ} \mathrm{C}\right)$ before recordings. Whole-cell patch recordings were performed at $35 \pm 0.5^{\circ} \mathrm{C}$ in layer II/III of the motor cortex. Neurons were visualized using infrared-differential interference contrast microscopy (Zeiss Axioskop). Recorded neurons were selected visually according to the somatic and dendritic morphology, mainly the apical dendrite characteristic to pyramidal neurons (see Fig. 7C). The extracellular solution (both for cutting and recording) contained (in mM) $125 \mathrm{NaCl}, 25$ glucose, $25 \mathrm{NaHCO}_{3}, 2.5 \mathrm{KCl}, 2 \mathrm{CaCl}_{2}, 1.25 \mathrm{NaH}_{2} \mathrm{PO}_{4}$, and $1 \mathrm{MgCl}_{2}$. Recordings were amplified using multiclamp $700 \mathrm{~B}$ amplifiers (Molecular Devices, Sunnyvale, CA), filtered at $2 \mathrm{kHz}$, digitized (5-20 kHz) using ITC-18 (Instrutech, Port Washington, NY), and acquired using PulseQ electrophysiology package (Funetics, Geneva, Switzerland) running on Igor Pro (Wavemetrics, Lake Oswego, OR). Patch pipettes with resistances of 5-10 M $\Omega$ were used for recordings and contained (in $\mathrm{mM}$ ) 110 K-gluconate, $10 \mathrm{KCl}, 10 \mathrm{HEPES}, 4 \mathrm{ATP}, 0.3 \mathrm{GTP}$, and 10 phosphocreatine. Electrophysiological characterization was performed by stepcurrent injections (see Fig. 7A), and synaptic connections were tested by evoking presynaptic trains of action potentials by injection of short (4 ms) square current pulses (see Fig. 7D). FS interneurons had characteristic nonaccommodating discharge pattern, high discharge frequency, and a large afterhyperpolarization. Non-FS interneurons had accommodating discharge responses, and in some cases also an initial burst preceding the graded accommodation (for a detailed description of interneuron classification, see Markram et al., 2004).

Gamma oscillations. Horizontal $400-\mu \mathrm{m}$-thick hippocampal slices were prepared from three mutant and three wt mice (P19-P22). Slices were maintained at room temperature at the interface between humidified carbogen gas $\left(95 \% \mathrm{O}_{2} / 5 \% \mathrm{CO}_{2}\right)$ and artificial CSF (ACSF) containing (in mM) $124 \mathrm{NaCl}, 3.5 \mathrm{KCl}, 1.25 \mathrm{NaH}_{2} \mathrm{PO}_{4}, 1.5 \mathrm{MgCl}_{2}, 1.5 \mathrm{CaCl}_{2}, 30$ $\mathrm{NaHCO}_{3}$, and 10 glucose for at least $1 \mathrm{~h}$ before recording. Recordings were made in stratum pyramidale of area $\mathrm{CA} 3$ in a submerged recording chamber $\left(32^{\circ} \mathrm{C}\right)$ using glass microelectrodes containing ACSF (resistance 3-5 M $\Omega$ ). Kainic acid was purchased from Sigma. Data were recorded with a MultiClamp 700B amplifier (Molecular Devices) and stored on a hard disk using pClamp 9.2 software (Molecular Devices). Fast Fourier transformations for power spectra were computed from 60-s-long data traces using Axograph software (Molecular Devices).

Stereological quantification of neurons. The densities of neurons in the motor and cingulate cortices were estimated using the optical fractionator method (West et al., 1991), which is unaffected by tissue shrinkage. Every fifth section from bregma level $1.1-0.38 \mathrm{~mm}$, where the areal borders are more distinguishable than in more caudal or rostral parts of the brain, were counted. The motor and cingulate cortices, delineated by the corpus callosum, somatosensory cortex and the pial surface of the brain using stereotaxic coordinates (Paxinos and Franklin, 2004) were outlined on coronal sections. The cingulate cortex, located adjacent to the motor cortex with a natural border at the midline of the brain was included to assure comparability of the sections. The border between the motor and somatosensory cortices is evident because of the narrowing of layer IV in the motor cortex. Consecutive sections with NeuN from the same animal were used to confirm the area when outlining the areal borders on sections stained with other markers.

Evenly distributed computer-generated counting frames were superimposed on the screen using the CAST-GRID 1.2 software (Olympus, Albertslund, Denmark). Five percent (PV adult mice, CB, NeuN, SOM), $10 \%$ (PV P14) or $20 \%$ (CR) of the region was counted on three (P14) or five (adult) sections from three to four mice per group as indicated in the figure legends. For every antibody and age, one region was counted three times to validate homogenous distribution of the cells, where the coefficient of variation $(\mathrm{SEM} /$ mean $\times 100 \%)$ was required to be $<10 \%$. The total counts of each section were calculated as follows: cell count $\times$ (total thickness of section/measured thickness) $\times$ (step length $X \times Y /$ area of counting frame), where the total thickness of the section was manually measured using the CAST software and the measured thickness is the total thickness minus $2 \mu \mathrm{m}$. To obtain the density, the total number of cells for each section was then divided by the volume of the section, which was the total thickness of the section, multiplied by the outlined area (a value automatically calculated by the software).

The thickness of layers II/III were measured using the CAST-GRID 1.2 software, as indicated in Figure $5 \mathrm{~A}$. The length was measured three times per section in the same three sections that were used for cells counts.

Statistical analysis. Data were analyzed using the Student's $t$ test (preceded by $F$ test for variances) or two-way ANOVA using the Prism 4 for Macintosh and InStat 3 for Macintosh softwares, followed by a Bonferroni or Tukey test to compare between groups. Differences were considered significant if $p<0.05$.

\section{Results}

\section{Identification of locomotor deficiencies}

Mice heterozygous for the TR $\alpha 1 \mathrm{R} 384 \mathrm{C}$ mutation $(\mathrm{TR} \alpha 1+/ m)$ have an impaired locomotor ability in the rotarod test (Venero et al., 2005). To define better the extent of this dysfunction, we applied the battery of tests in the SHIRPA primary screen (Rogers et al., 1997; Hatcher et al., 2001). Of the 38 tests, five behavioral abnormalities and four motor defects were identified: reduced grip strength and increased limb tone, as well as impairment in the wire maneuver and negative geotaxis tests (data not shown, available on request).

To decide whether the motor dysfunctions observed in the SHIRPA tests were caused by irreversible developmental defects, we treated one group of mice with postnatal injections (P10P35) and another group with TH in their drinking water for $12 \mathrm{~d}$ during adulthood, both with concentrations that have been shown previously to activate the mutant receptor (Venero et al., 2005). All animals were then tested as adults. None of the treatments restored the motor skills of the mutant mice to normal, suggesting that the defects were founded during earlier development (data not shown, available on request).

To allow a better quantification of the motor dysfunctions, we applied the robust hanging wire test. Adult mutant mice performed poorly, in contrast to wt mice of which a majority could perform the task (Fig. $1 A)(p<0.01)$. In concurrence with what was seen in the SHIRPA primary screen, neither juvenile nor adult $\mathrm{TH}$ treatments were able to rescue the reduced motor skill of the mutant mice (Fig. 1A). To determine whether the poor performance correlated with reduced muscle strength of the limbs, a grip strength meter was used. Figure $1 B$ shows that the 
A

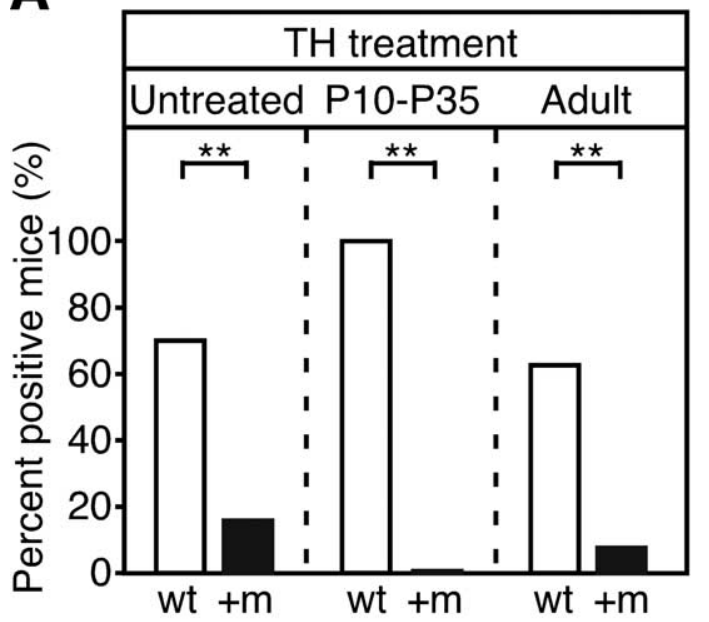

B
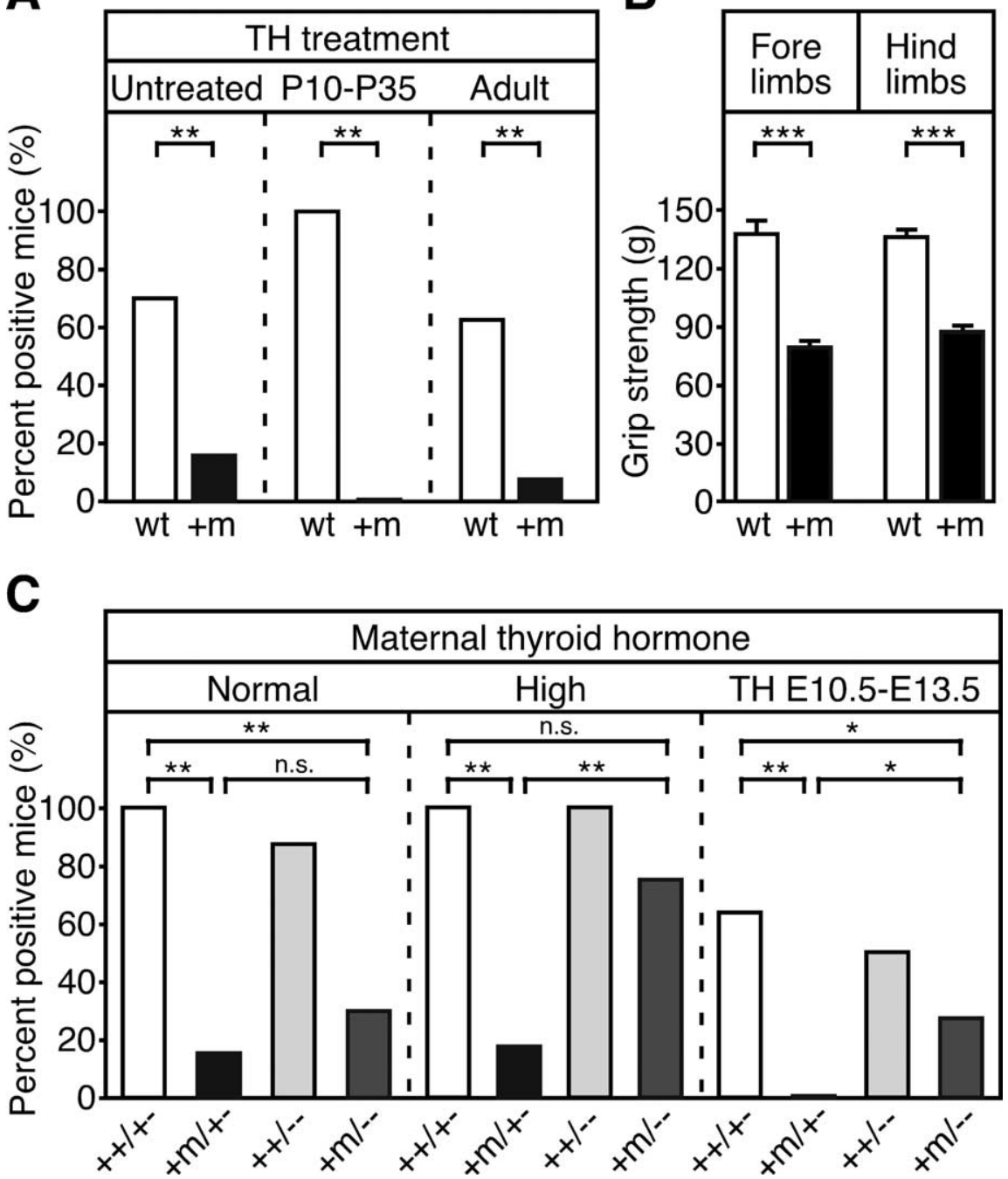

Figure 1. Improved performance in the hanging wire test by a combination of fetal and postnatal TH treatment. $A, C$, To score fully functional in the hanging wire test, adult wt and mutant mice had to cling to a wire cage lid for $60 \mathrm{~s}$. Untreated $T R \alpha 1+/ m$ $(+\mathrm{m})$ mice show impaired performance in the test. Injection of TH during P10 -P35 or adult TH treatment for $12 \mathrm{~d}$ fail to improve the performance of the mutant mice $(n=8-25$ per group; $A)$. $B$, Reduced muscle strength of $T R \alpha 1+/ m$ mice in both fore and hindlimbs as determined by a grip strength meter $(n=12)$. C, Hanging wire performance in $T R \alpha 1+/ m$ mice that have a TR $\beta$ null allele. TR $\beta$ deficiency causes an increase in TH levels sufficient to activate the mutant TR $\alpha 1$ aporeceptor. Progeny exposed to normal or high maternal TH were bred from $\operatorname{TR} \alpha 1+/+\beta+/-(++/+-)$ and $\operatorname{TR} \alpha 1+/ \mathrm{m} \beta-/-(+\mathrm{m} /--)$ dams, respectively. The left panel shows no difference between $T R \alpha 1+/ m \beta-/-$ and $T R \alpha 1+/ m \beta+/-(+\mathrm{m} /+-)$ mutant mice from dams with normal maternal TH. The middle panel shows that $T R \alpha 1+/ m \beta-/-$ mice exposed to elevated levels of TH during both fetal and postnatal development have an improved performance. The right panel shows the effect on the progeny of pregnant $T R \alpha 1+/ m \beta+/-$ dams treated with high TH levels during E10.5-E13.5. The $T R \alpha 1+/ m \beta-/-$ progeny show an increased capacity to cling to the grid compared with $\operatorname{TR} \alpha 1+/ \mathrm{m} \beta+/-$ littermates ( $n=6-17$ per group). Data are presented as mean \pm SEM. ${ }^{*} p<0.05 ;{ }^{* *} p<0.01 ;{ }^{* * *} p<0.001$ (Student'st test). n.s., Not significant; $++/--, \operatorname{TR} \alpha 1+/+\beta-/-$.

2002). To determine whether supply of TH from the pregnant mother to the fetus is needed for development of the tested motor skills, we also performed the tests with progeny of $T R \alpha 1+/ m \beta-/-$ dams. This would allow exposure of the fetus to high levels of TH throughout development (Forrest et al., 1996).

$T R \alpha 1+/ m \beta-/-$ mice exposed to normal TH levels during fetal development did not improve their performance in the hanging wire test compared with $T R \alpha 1+/$ $m \beta+/-$ controls (Fig. 1C, left). However, high maternal $\mathrm{TH}$ restored the performance, as there is no significant difference between the $T R \alpha 1+/ m \beta-/-$ mice and wt controls (Fig. $1 C$, middle). In this experiment the TR $\alpha 1+/ m \beta+/-$ littermates did not improve $(p<0.01)$, indicating that high levels of $\mathrm{TH}$ during embryogenesis alone are not sufficient to normalize the motor skills, and that high $\mathrm{TH}$ is needed also at later stages of development. These results corroborated the results of the SHIRPA screen (data not shown; available on request), $w$ here $T R \alpha 1+$ / $m \beta-/-$ mice from both dams with normal TH and dams with high TH improved their performance compared with TR $\alpha 1+/$ $m \beta+/-$ control mice.

To define further the time period when the embryo is dependent on maternal $\mathrm{TH}$ for restoration of performance in the hanging wire test, we treated $T R \alpha 1+/+\beta+/-$ dams crossed to $T R \alpha 1+/ m \beta-/-$ male mice with $\mathrm{TH}$ in their drinking water during embryonic day 10.5 (E10.5)-E13.5, in addition to the elevated $\mathrm{TH}$ levels from late fetal development throughout life. The progeny was tested for hanging wire performance as adults. These mice improved significantly $(p<0.05)$, compared with littermates that received only maternal $\mathrm{TH}$ (Fig. 1C, right). We conclude that the mouse embryo is dependent on maternal TH during E10.5-E13.5 in combination with its own production of $\mathrm{TH}$ at later developmental stages for proper development of motor skills needed for the hanging wire test.

\section{Beam walk and footprint analysis}

mutant mice had reduced grip strength of both forelimbs and hindlimbs $(p<0.001)$. This is however not caused by a muscle defect because in vitro measurements and quantification of myosin heavy chain protein of EDL (fast-twitch) and soleus (mainly slow-twitch) muscles demonstrated skeletal muscle function to be largely normal (data not shown; available on request).

We then tested whether the motor defects could be normalized by activating the mutant receptor during embryonic or early postnatal life. For this, we used a mouse strain heterozygous for $\operatorname{TR} \alpha 1 \mathrm{R} 384 \mathrm{C}$ that also has null alleles for $\mathrm{TR} \beta$. These mice have 10fold elevated serum TH levels, which allows activation of the mutant receptor from late fetal development throughout life (Tinnikov et al.,
To clarify whether the motor defects revealed by the SHIRPA primary level screen and the hanging wire test were reflected in other testing paradigms, the beam walk test and footprint analysis were done. Figure $2 A$ shows that the mutant mice exhibited more hindlimb slips in the beam walk than wt controls ( $p<0.05,21 \mathrm{~mm}$ square beam; $p<0.01$, $12 \mathrm{~mm}$ square and round beams). The inability of the mutants to walk on square and round beams of $21 \mathrm{~mm}$ width was restored by adult $\mathrm{TH}$ treatment (Fig. 2C). In contrast, neither juvenile nor adult treatment could normalize the performance on narrower beams (Fig. $2 B, C$ ). Similar results were obtained with $T R \alpha 1+/ m \beta-/-$ mice that had received normal maternal TH (Fig. 2D).

The results of the footprint analysis show that mutant mice 
A Untreated mice

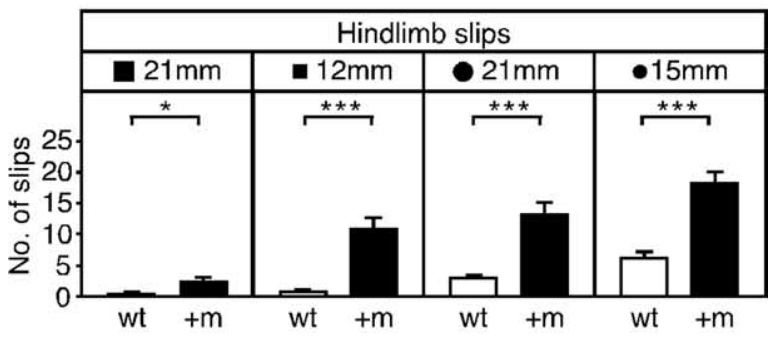

B Mice TH-treated P10-P35

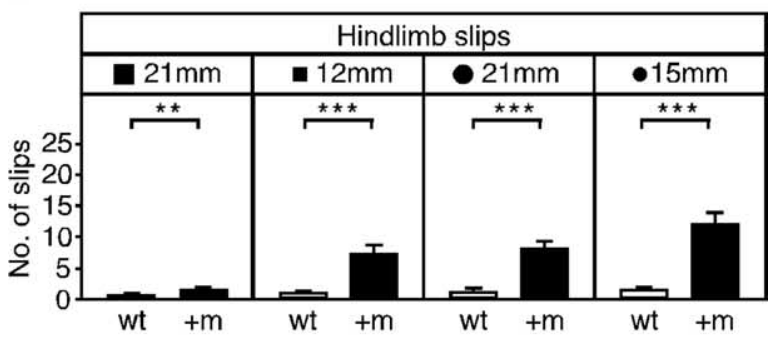

C Mice TH-treated as adults

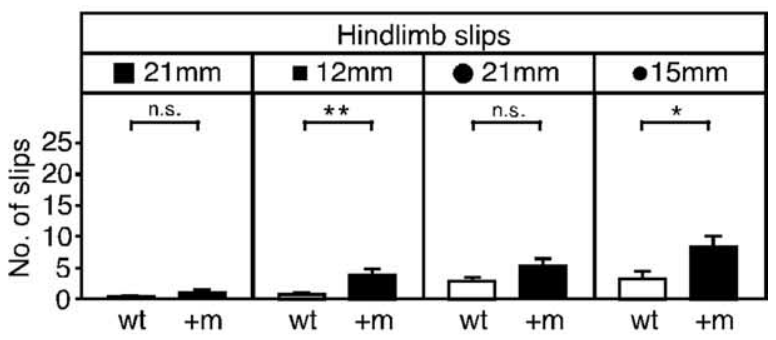

D ++ +t- dams
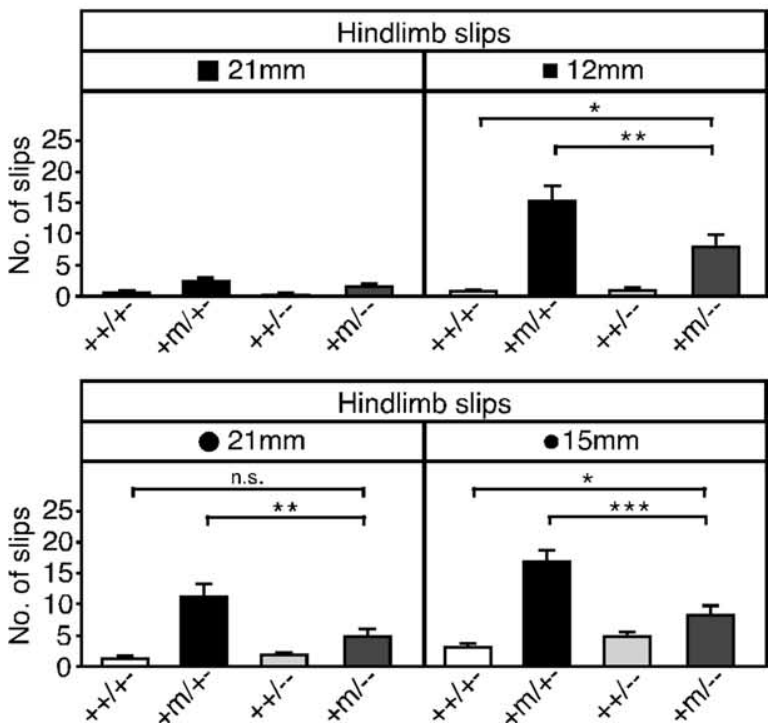

Figure 2. Reduced limb coordination in the beam walk test. $\boldsymbol{A}-\boldsymbol{D}$, Adult mice were trained on a wide beam for $3 \mathrm{~d}$, and tested on the fourth day for performance on square and round beams of different dimensions as indicated in the figures. Untreated $T R \alpha 1+/ m(+\mathrm{m})$ mice make significantly more hindlimb slips in the beam walk test compared with wt controls $(n=$ 9-10 per group; $A)$. TH injections during P10 -P35 fail to improve limb coordination of the mutants $(n=7-9$ per group; $\boldsymbol{B})$. Adult TH treatment restores limb coordination of the mutant mice on square and round beams of $21 \mathrm{~mm}$ width, and improves their performance on narrower beams ( $n=9-10$ per group; $C$. Improved performance of $T R \alpha 1+/ m \beta-/-(+\mathrm{m} /--)$ mice that have 10 -fold elevated TH levels in the beam walk test $(n=9-11$ per group; $\boldsymbol{D})$. Data are presented as mean \pm SEM. ${ }^{*} p<0.05 ;{ }^{* *} p<0.01 ;{ }^{* * *} p<0.001$ [Student's $t$ test $(\boldsymbol{A}-\boldsymbol{C})$ or Bonferroni test preceded by two-way ANOVA (D)]. $++/+-, \operatorname{TR} \alpha 1+/+\beta+/-;+\mathrm{m} /$ ,$+- \operatorname{TR} \alpha 1+/ m \beta+/-;++/--, \operatorname{TR} \alpha 1+/+\beta-/-$. take significantly shorter strides than wt controls (Fig. $3 B)(p<$ 0.001 , top left). No effect was seen by either juvenile or adult TH treatment (Fig. 3B, middle and bottom left). However, TR $\alpha 1+/$ $m \beta-/-$ mice from both dams with normal and high maternal $\mathrm{TH}$ showed an increase in stride length compared with $T R \alpha 1+/$ $m \beta+/-$ controls (Fig. 3C, supplemental Fig. 2, available at www. jneurosci.org as supplemental material), suggesting that an active receptor from late fetal development and onwards is required to ameliorate this insult. This is in contrast with the results obtained in the hanging wire test where the receptor had to be activated already during early embryonic development for correct performance in the test.

Furthermore, the mutant mice walk with their hind paws everted (Fig. $3 B$, right) $(p<0.01)$. This defect was normalized only by adult TH treatment, indicating an adult effect of the mutant receptor. The tendency of the mutant mice to walk on their heels is evident in the TR $\alpha 1+/ m \beta-/-$ and TR $\alpha 1+/$ $m \beta+/-$ mice that have a higher incidence of heel usage than wt mice (Fig. 3C, right).

No difference was seen between mutant and wt mice in base width (supplemental Fig. 2, available at www.jneurosci.org as supplemental material). The slight reduction seen in interstep distance is not present in the TR $\alpha 1+/ m \beta+/-$ mice (supplemental Fig. 2, available at www.jneurosci.org as supplemental material), indicating that this feature may represent a weak effect of the mutant TR $\alpha 1$.

\section{Normal muscle innervation}

To identify the tissue(s) affected by the mutant receptor that cause locomotor abnormalities we systematically examined tissues controlling motor function. Because a solely muscular defect could be excluded (as mentioned above) we next examined innervation of the muscles. Transgenic Xenopus laevis tadpoles expressing a dominant-negative TR have reduced motor neuron innervation of their hindlimbs along with defective neuromuscular junctions (Marsh-Armstrong et al., 2004) and we accordingly examined the clustering of acetylcholine receptors (AChR) at nerve terminals on whole hind muscle preparations. However, at E18.5 no abnormalities at neuromuscular junctions of mutant mice were found (data not shown, available on request).

$\mathrm{TH}$ is implicated in myelination through regulation of myelin basic protein (Rogister et al., 1999), and we therefore examined the sciatic nerve and the dorsal and ventral roots at the lumbar spinal cord level for any alterations in myelination with toluidine staining of semithin sections. No gross aberrancies in motor or sensory neuron nerve bundles were observed (data not shown, available on request).

\section{Delayed appearance of GABAergic interneurons in the neocortex}

We hypothesized that a low number of GABAergic interneurons in brain regions controlling movement was the cause of the identified locomotor impairments, because adult $T R \alpha 1+/ m$ mice have a reduced number of PV-IR cells in the CA1 region of the hippocampus (Venero et al., 2005). Because the locomotor dysfunctions are caused by developmental events we examined the appearance of PV-IR cells at P14-P33 in the motor cortex. At P14, the TR $\alpha 1+/ m$ mice showed a dramatic reduction in PV-IR neurons compared with wt mice (Fig. $4 A, D)(p<0.01)$. The same result was obtained in the somatosensory cortex (data not shown). The reduction in immunoreactivity was evident at both P17 and P25, but started to normalize around P33. In the adult mice the cell density was restored to wt levels (Fig. $4 A, D$ ). To 
A

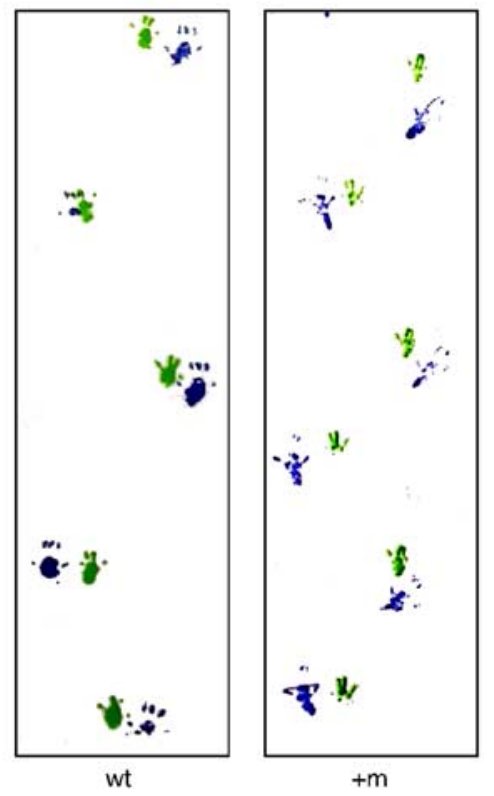

B Untreated mice

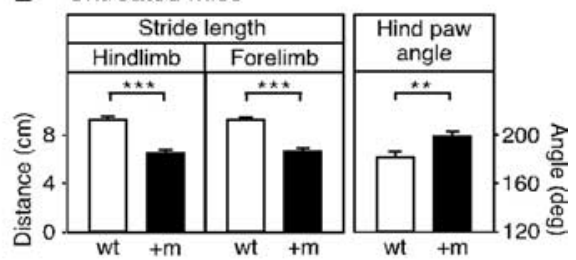

Mice TH-treated P10-P35

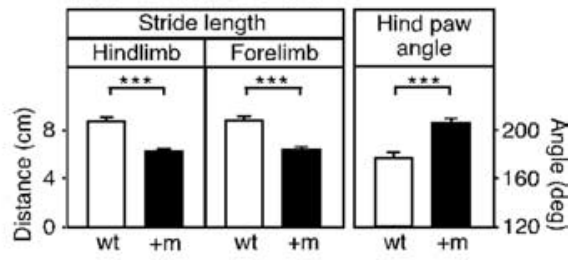

Mice TH-treated as adults

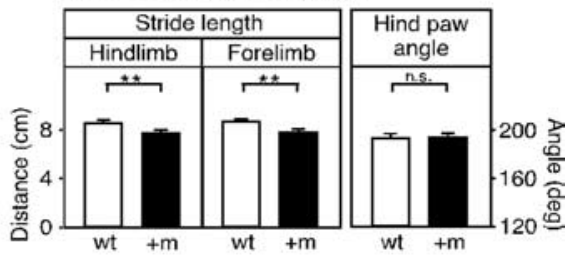

C ++ +t- dams
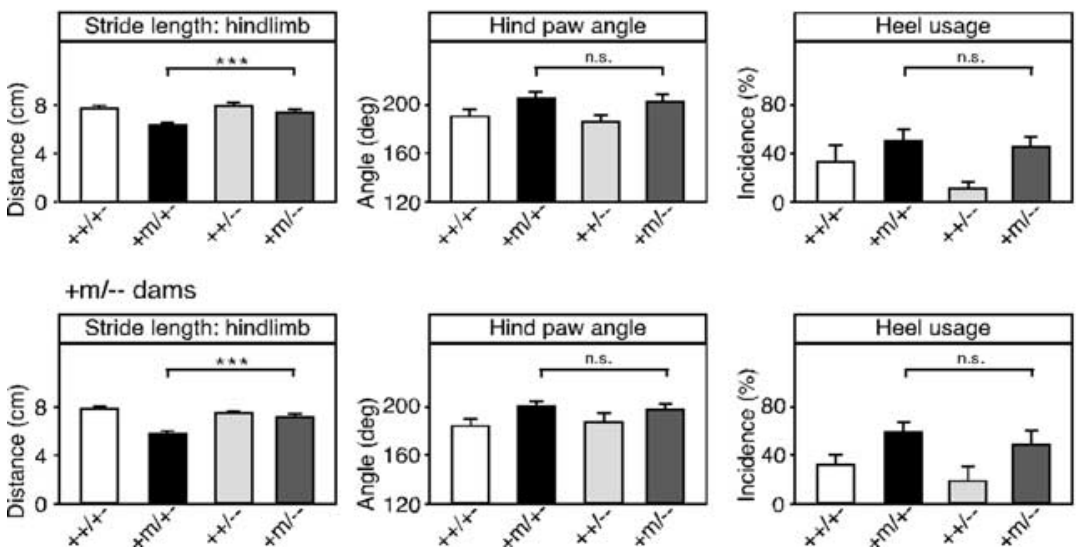

Figure 3. Footprint analysis. $\boldsymbol{A}-\boldsymbol{C}$, Adult wt and mutant mice were subjected to a footprint analysis over an $80 \mathrm{~cm}$ distance. $\boldsymbol{A}$, Representative footprints from $T R \alpha 1+/ m(+\mathrm{m})$ and control animals. $\boldsymbol{B}$, Stride length and hind paw posture of $T R \alpha 1+/ \mathrm{m}$ mice. TH administrations were done by injections during P10 - P35 or by addition of hormone to drinking water for adult mice $(n=$ 8-16 per group). $C$, Increased stride length in $T R \alpha 1+/ m \beta-/-(+\mathrm{m} /--)$ mice from dams with normal or high TH levels compared with $T R \alpha 1+/ m \beta+/-(+\mathrm{m} /+-)$ mutant mice. No effect was seen for hind paw angle. Both $T R \alpha 1+/ m \beta-/-$ and $T R \alpha 1+/ m \beta+/-$ mutant mice have a higher incidence of heel usage, illustrating the tendency of the mutants to walk on their heels ( $n=6-10$ per group). Data are presented as mean \pm SEM. ${ }^{* *} p<0.01 ;{ }^{* * *} p<0.001(\boldsymbol{A}, \boldsymbol{B}$, Student's $t$ test; $\boldsymbol{C}$, Bonferroni test preceded by two-way ANOVA). $++1+-, \operatorname{TR} \alpha 1+/+\beta+/-;++/--, \operatorname{TR} \alpha 1+/+\beta-/-$.

During the second postnatal week, CB-IR cells in layers II/III appear in both pyramidal and local circuit neurons (Alcantara et al., 1993; Cobos et al., 2005). When estimating the density of CB-IR cells excluding layers I-III (no CB-IR cells were observed in layer I), no difference in cell density were found at $\mathrm{P} 14$ or in adult mice (Fig. $5 A, C$ ). In contrast, a decreased density of CB-IR cells in layers II/III was evident in the mutant mice (Fig. $5 A, D)(p<$ $0.05)$ and the thickness of these layers was indeed decreased at P14 (Fig. $5 A, D)(p<$ $0.05)$. Staining for NeuN revealed a small reduction in cell density at $\mathrm{P} 14$, whereas adult tissue was normal (Fig. 5A,B) $(p<$ $0.05)$. Both the reduced density of neurons and the decreased density of CB-IR cells, which is potentially accounted for by pyramidal cells, are likely to reflect the previously reported overall delayed postnatal development of the mutant mice (Tinnikov et al., 2002). However, the decreased thickness of layers II/III may also indicate an aberrant tissue architecture.

In conclusion, the mutation in TR $\alpha 1$ caused abnormalities in the GABAergic system specific for the PV and CR subclasses. The effects are however different in the two cell types, with a developmental delay affecting PV-IR cells and an increased number of CR-IR cells in the adult mice.

\section{Rescue with perinatal TH treatment}

The apparent reduced number of PV-IR cells in the mutant mice could either reflect that the cells are missing, have a delayed maturation program, retarded migration or be caused by low expression of antigen. To test whether the reduced number of immunoreactive cells was caused by dysregulation of antigen expression by the unliganded receptor, we injected mutant and wt mice daily at P11-P13 with TH, estimating that this time would allow induction of PV by the hormone, but be too short to influence cell migration into the neocortex and maturation. The concentrations of $\mathrm{TH}$

examine whether the reduced number of PV-IR cells was associated with an overall reduction in GABAergic neurons, we stained for GAD67, the enzyme in GABAergic cells that catalyzes the formation of GABA from glutamate. The results in Figure 5, A and $C$, show that the number of GAD67-IR cells was unaltered in P14 and adult mutant mice.

To investigate whether the delayed appearance of PV-IR cells was specific for this class of GABAergic interneurons, we estimated the densities of CR-, CB-, and SOM-immunoreactive cells in the motor cortex of mutant mice. Interestingly, the result showed a tendency for an increased number of CR-IR cells in the mutants at P14. Subsequently, the adult mutant mice were found to contain an increased density of CR-IR cells (Fig. 5A, C) $(p<$ 0.05 ) whereas the numbers of SOM-IR cells were normal at both $\mathrm{P} 14$ and in the adult (Fig. $5 \mathrm{~A}, \mathrm{C}$ ). were the same as used for the locomotor studies, and the mice were killed at P14. The result showed that the number of PV-IR cells failed to normalize in the mutants, and indicate that unliganded TR $\alpha 1$ causes a defect in migration and/or maturation of these cells (Fig. $4 B$ ).

Neocortical GABAergic interneurons of the PV subclass are generated from E11.5 during embryogenesis in the medial ganglionic eminence (MGE) and migrate tangentially to the cortical plate (Nadarajah and Parnavelas, 2002; Marin and Rubenstein, 2003), where the first PV-IR cells appear at P10 (Hof et al., 1999). We confirmed the latter in the wt mice (data not shown). To investigate whether activation of the mutant TR $\alpha 1$ during these time periods could rescue the development of PV-IR cells, we studied their appearance in $T R \alpha 1+/ m \beta-/-$ mice that had been exposed to normal or high maternal TH levels. The high levels of 
TH in the TR $\alpha 1+/ m \beta-/-$ mice increased the number of PV-IR cells in the motor (Fig. 4C) and somatosensory cortices (data not shown), whereas the number of cells in the $T R \alpha 1+/ m \beta+/-$ littermates that have normal levels of TH remained low. High maternal TH did not further increase the number of PV-IR cells than what was already achieved in the $T R \alpha 1+/ m \beta-/-$ mice (data not shown).

In conclusion, the delayed appearance of PV-IR cells was partially restored by high levels of TH from around birth. Because a $3 \mathrm{~d}$ treatment with $\mathrm{TH}$ failed to yield the same result, the effect of TR $\alpha 1$ on PV is not by regulating antigen expression, but rather on the migration or maturation process of the cells.

\section{General developmental delay of cerebellar GABAergic neurons}

The TR $\alpha 1+/ m$ mice have a delayed maturation of the cerebellum during postnatal development (Venero et al., 2005). To determine whether the cortical abnormalities in immunoreactivity to calcium binding proteins also were seen in the cerebellum, we performed immunohistochemistry on postnatal and adult mice with antibodies to PV, CB, and CR. The result revealed a general retardation in cerebellar development, as all three markers showed a co-ordinately delayed appearance (Fig. 6). The delay was evident at P9, but was completely (CB and $\mathrm{CR}$ ) or nearly (PV) normalized only a few days later. No differences in staining intensity or distribution of cells were evident in the adult mice. The delayed maturation of cerebellar GABAergic neurons therefore differs from that in the neocortex in that it affects all markers temporally equally compared with the subtype-specific alterations seen in the cortex.

\section{Electrophysiological properties of GABAergic cells}

To assess whether a reduced number of PV-IR interneurons leads to functional impairment in the cortex of the TR $\alpha 1$ mutant mice, two different electrophysiological parameters were tested. Because PV-IR cells correspond to the FS type of interneurons, we determined the prevalence of such cells in neocortical layers II/III of P19-P21 mutant mice. Whole-cell patch-clamp recordings were obtained from neurons in neocortical slices from the motor and somatosensory cortices, and cells were divided into FS and non-FS neurons according to their discharge response to a step-current injection. A 10-fold decrease in the prevalence of FS neurons was found in the mutant compared with wt mice (Fig. $7 A, B)(1 / 35$ vs $6 / 20$ FS cells/number of recordings; $3 \%$ vs $30 \%$, respectively). The patch-clamp recordings therefore corroborate the immunohistochemical finding. Furthermore, the neocortex of mutant mice contained non-FS interneurons, which were synaptically interconnected with pyramidal neurons in a similar manner as seen in other cortical circuits (Silberberg and Markram, 2007) (Fig. 7C,D), suggesting that the impairment is selective to a subpopulation of interneurons.

To test whether the low number of PV-IR interneurons in the mutants affects the characteristics of rhythmic network oscillations in the gamma frequency range $(20-80 \mathrm{~Hz})$, extracellular field recordings were obtained from stratum pyramidale in hippocampal slices before and after application of $100 \mathrm{~nm}$ kainate. The oscillation frequency was significantly lower in the mutant mice compared with wt (Fig. $8 C$ ) (mutant, $23.3 \pm 1.0 \mathrm{~Hz}$; wt, $28.3 \pm 1.1 \mathrm{~Hz}$; mean $\pm \mathrm{SEM}, p<0.01)$. In contrast there was no difference in oscillation strength (Fig. $8 \mathrm{~B}$ ) (mutant, $1.08 \times 10^{-6} \pm$ $5.40 \times 10^{-7} \mathrm{~V}^{2} ; \mathrm{wt}, 7.06 \times 10^{-7} \pm 3.03 \times 10^{-7} \mathrm{~V}^{2} ;$ mean $\pm \mathrm{SEM}$, $p>0.5)$.

These data are in agreement with our demonstration that 

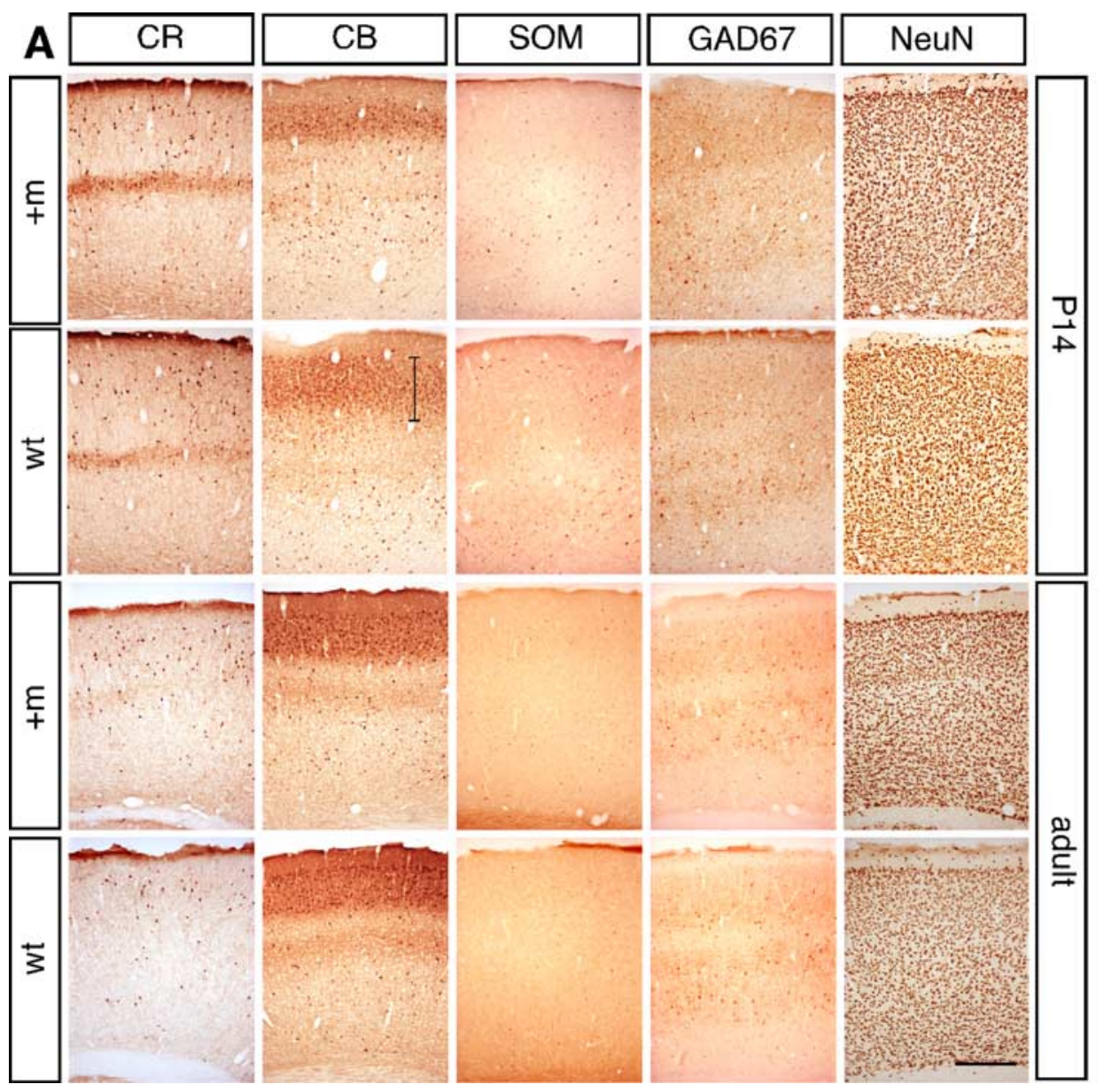

B

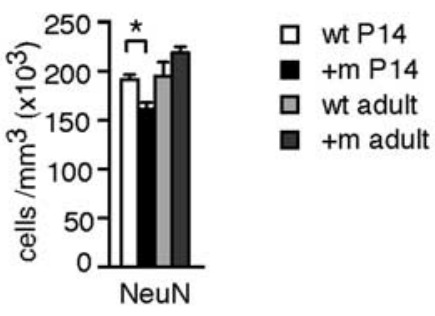

\section{C}

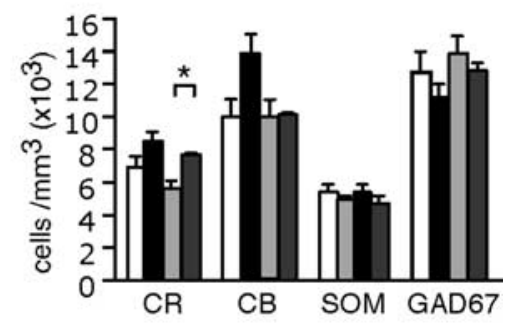

D

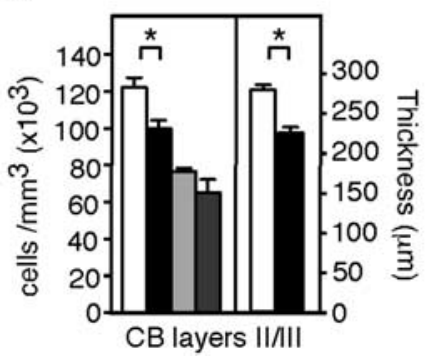

Figure 5. Development of specific classes of GABAergic interneurons in the motor cortex. $A$, Sections of P14 and adult mice were immunostained for CR, CB, SOM, GAD67 (GABA-containing neurons), and NeuN (neurons). Scale bar, $160 \mu \mathrm{m}$. B-D, Densities of NeuN (B), CR, CB, (excluding layers I-III), SOM and GAD67 (C), and CB-IR (layers II/III) (D) at P14 (white, wt; black, mutant) and in adult mice (light gray, wt; dark gray, mutant). Dalso includes thickness of layers II/III measured in sections immunostained for (B at P14 (white, wt; black, mutant). Data are presented as mean \pm SEM, ${ }^{*} p<0.05$ (Student's $t$ test). $n=3$ or 4 (adult NeuN). The bar in CB/wt indicates layers II/III. $+\mathrm{m}, T R \alpha 1+/ m$.

PV-IR cells are delayed in their appearance, and indicates that the mistimed cellular development results in major aberrancies.

\section{Thyroid hormone levels}

Previously, it was shown that TH levels are elevated in adult $T R \alpha 1+/ m \beta-/-$ mice (Tinnikov et al., 2002). To verify that serum and tissue levels of TH are also increased during early postnatal development, serum total thyroxine (TT4), triidothyronine (T3), and cerebellar T3 and T4 levels were determined at postnatal days 1, 6, 11,22, and 33 and postnatal days 1, 11, and 33, respectively. All serum and tissue TH values are provided in supplemental Figures 3 and 4 (available at www.jneurosci.org as supplemental material). Already at P1, serum TT4 was increased 14-fold in the TR $\alpha 1+/ m \beta-/-$ mice compared with $T R \alpha 1+/$ $m \beta+/-$ controls. The same pattern was seen for all time points measured. Interestingly, at P11, there was a small decrease in serum TT4 in the TR $\alpha 1+/ m \beta+/-$ mice compared with $T R \alpha 1+/+$ $\beta+/-$ controls. This difference is however normalized at P22, which is in agreement with the transient juvenile hypothyroidism reported previously (Tinnikov et al., 2002). To determine whether high maternal supply of TH had an effect on postnatal TH levels, we also measured the levels of serum TT4 in the progeny from $T R \alpha 1+/ m \beta-/-$ dams. We noted that at P1, there was a tendency toward increased serum TT4 in the TR $\alpha 1+/ m \beta+/-$ mice exposed to high maternal $\mathrm{TH}$, compared with $T R \alpha 1+$ / $m \beta+/-$ mice with normal maternal TH. This tendency is however not seen at any other time point, suggesting that exposure to high maternal TH does not have a lasting effect on the hypothalamus-pituitary-thyroid axis.

The cerebellar tissue concentration of T4 and T3 followed the pattern of serum TT4, demonstrating that the high levels of TH also were present at the tissue level in TR $\alpha 1+/ m \beta-/-$ mice. Moreover, the tendency toward increased serum TT4 at P1 in $T R \alpha 1+/ m \beta+/-$ mice with high maternal TH was also reflected in the T4 cerebellar levels. This effect was however not translated into cerebellar T3 levels where no difference was seen between $T R \alpha 1+/ m \beta+/-$ mice with high or normal maternal TH respectively. Cerebellar T3 and T4 levels were also measured in $T R \alpha 1+/ m$ and control mice. For these mice, no statistical difference was noted.

\section{Discussion}

In this study, we show that a receptor-mediated hypothyroidism during mouse development causes locomotor dysfunctions that correlate with improper appearance of subtype-specific GABAergic interneurons in the neocortex. These dysfunctions were of both embryonic and postnatal origin and we show that the defects could be reversed or ameliorated by maternal or late prenatal TH treatment in combination with elevated TH levels after birth.

We provide an assay that for the first time can be used to 
quantify a locomotor dysfunction in the adult mouse that was caused by deficient TH signaling during fetal/perinatal development. In addition, two highly specific cell types, PV and CR subtypes of GABAergic interneurons, important for motor control, are shown to misdevelop as a consequence of $\mathrm{TH}$ deficiency. Although $\mathrm{TH}$ has been implicated previously in the development of the GABAergic system (Berbel et al., 1996; Guadano-Ferraz et al., 2003; Venero et al., 2005; Gilbert et al., 2007), we show here that this property is specific for the PV and CR subtypes, and that the unliganded TR $\alpha 1$ exerts distinct effects on these two cell types with a developmental delay affecting PV-IR cells and an increase in the number of CR-IR cells in the adult mouse. In contrast to this, in the cerebellum, the development of both PV-, CB-, and CR-IR cells were equally delayed, which reflects the general effect of the $\mathrm{TR} \alpha 1$ aporeceptor to retard development.

\section{Locomotor dysfunctions}

Similar to what has been described for neurological cretins, the locomotor dysfunctions of the $T R \alpha 1+/ m$ mice are complex and range from poor neuromuscular force to defects in limb coordination and abnormal gait with everted hind paws and increased heel usage.

That TH affects critical events during extended periods of development is highlighted by the hanging wire and locomotor tests. High maternal TH during embryogenesis improved the performance of the mutant mice in the hanging wire test only when combined with continued high levels of $\mathrm{TH}$ at later stages of development. The embryonic stage at which maternal $\mathrm{TH}$ is needed was identified by two independent approaches. The improvement seen in the TR $\alpha 1+/ m \beta-/-$ mice born by dams with high TH levels, but not by dams with normal gestational hormone levels limits a critical event to not later than E18.5 when the fetal thyroid gland becomes functional. The partial recovery observed after treating pregnant dams with $\mathrm{TH}$ in the drinking water between E10.5 and E13.5 of gestation indicates an earliest time at $\sim$ E10.5. This window of time is in agreement with the estimate that human locomotor development becomes irreparably damaged by maternal hypothyroxinemia during the first to second trimester interface (Morreale de Escobar et al., 2004). In addition, the $T R \alpha 1+/ m$ mice demonstrated impaired capacity in the beam walk test and footprint analysis that could also be ameliorated with $\mathrm{TH}$ treatment. However, the rescue pattern in these tests was more complex, involving both prenatal, postnatal as well as adult components.

Our locomotor data thus provide three significant results: (1) that the mouse embryo is dependent on $\mathrm{TH}$ for proper nervous system development of a specific and quantifiable motor skill, (2) that, for this, maternal TH supply is required during the transition from embryonal to fetal development of the mouse, and (3)

P14
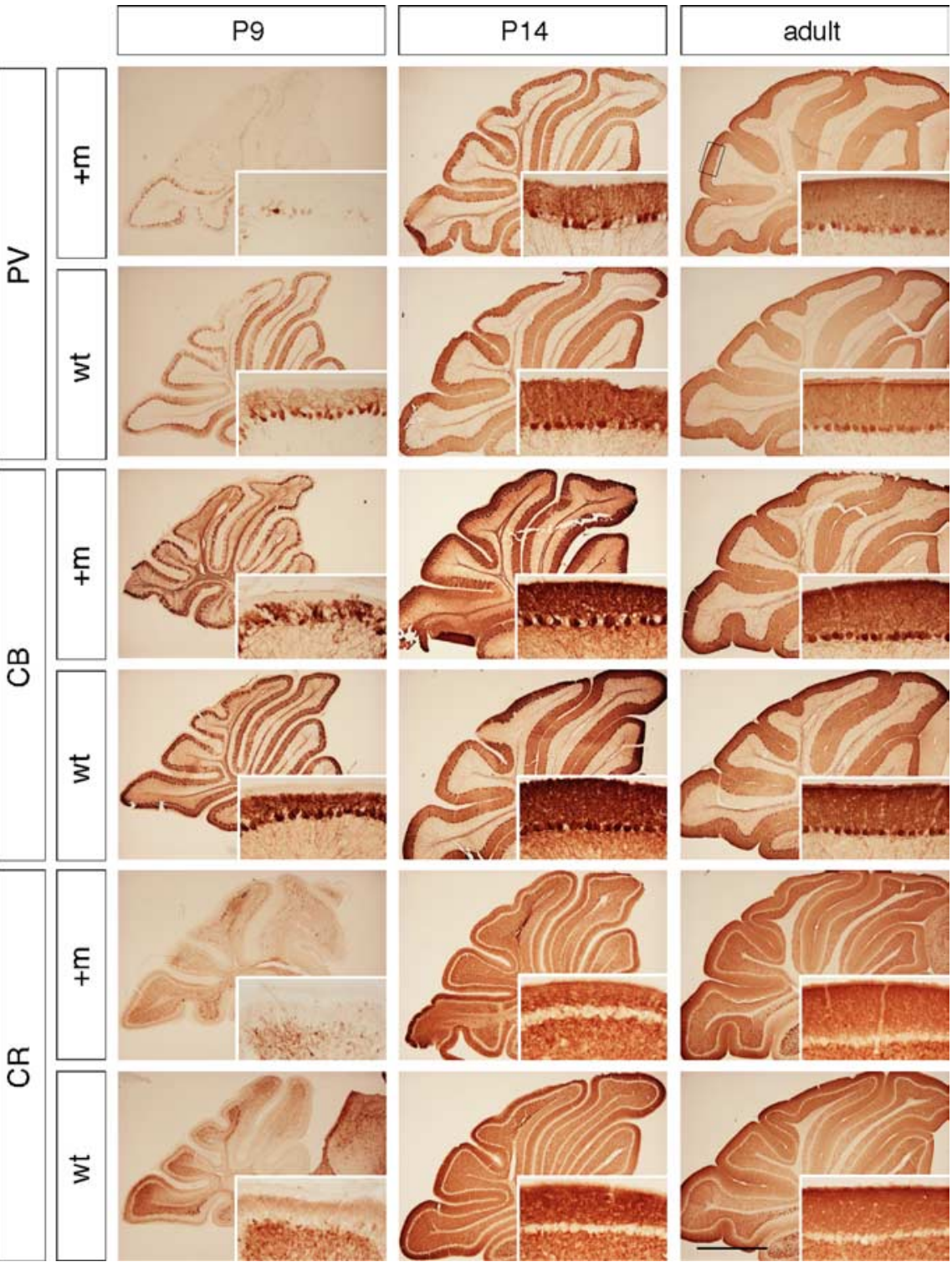

Figure 6. General delayed postnatal development of the cerebellum. Cerebellum of P9, P14, and adult mice immunostained for PV, CB, and CR show a delayed postnatal development in the mutants. Insets show high magnification of lobe VIII (boxed area). $n=2$ (P9); $n=3$ (P14, adult). Scale bar, $400 \mu \mathrm{m}$. +m, TR $\alpha 1+/ m$.

that the unliganded TR $\alpha 1$ isoform causes a severe misdevelopment of locomotor abilities that is irreparable during later stages in life.

\section{Development of interneurons}

The in vitro measurements of muscle function and the examination of motor end plates and myelination suggested that the locomotor abnormalities were not caused by dysfunctional muscle innervation. Instead, the nature of the locomotor dysfunctions prompted us to investigate the development of interneurons in brain areas controlling motor function (i.e., the motor and somatosensory cortices).

Cortical PV-IR interneurons were fewer in postnatal mutant mice, whereas these cells showed normal histology in the adult, demonstrating that the mutant TR $\alpha 1$ does not preclude the birth and proliferation of immature interneurons. That a 3 d treatment with pharmacological doses of TH during P10P13 failed to normalize the immunostaining indicates that expression of the PV antigen is not dependent on the hor- 

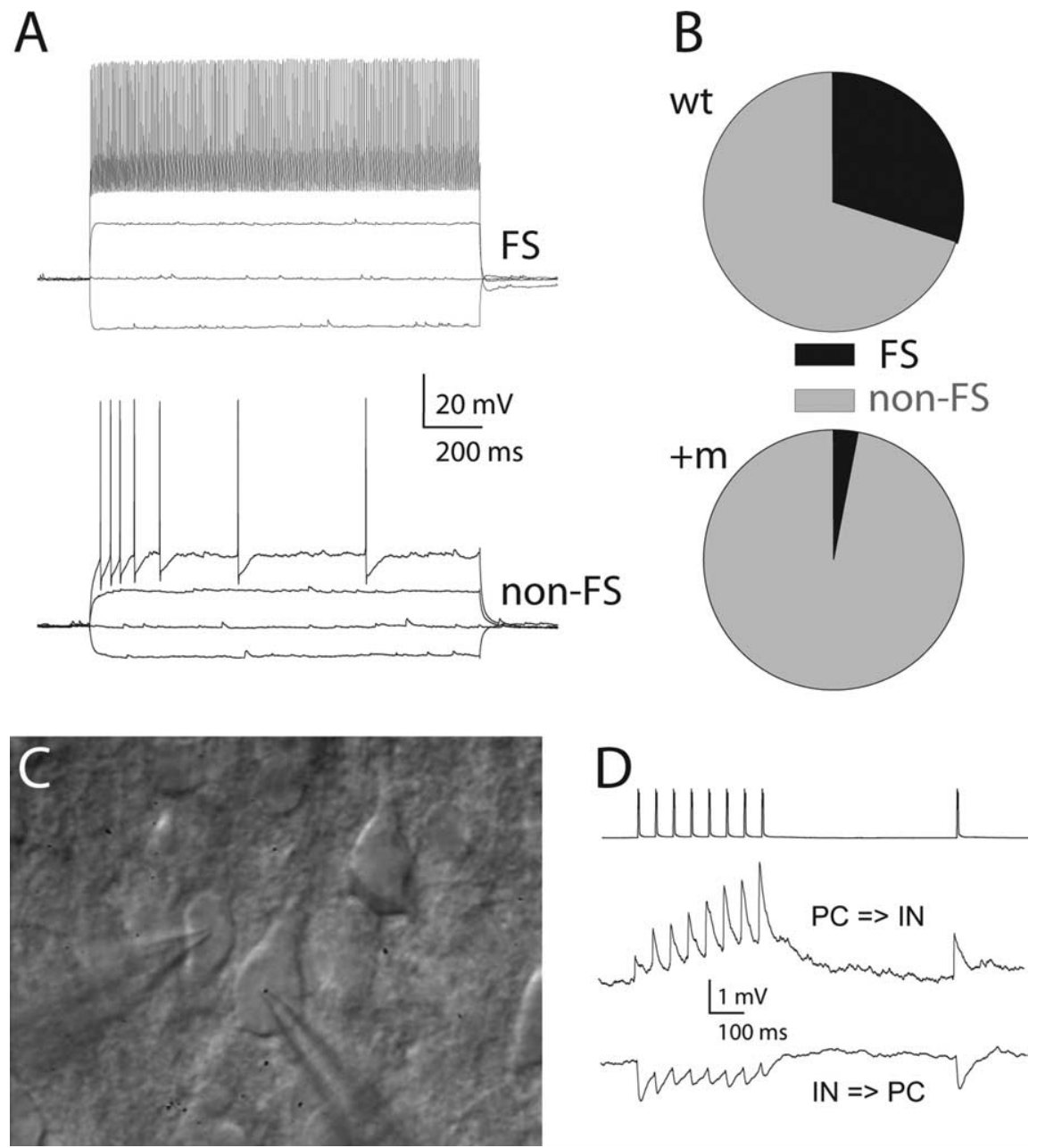

Figure 7. Fewer FS interneurons but preserved connectivity of non-FS interneurons. $\boldsymbol{A}$, Example of voltage response to step-current injections in FS (top traces) and non-FS (bottom traces) interneurons. Note the high discharge frequency characteristic of the FS interneuron, and the accommodation of the non-FS interneuron. $\boldsymbol{B}$, Prevalence of FS interneurons in wt mice was $30 \%$ ( 6 of 20 ) and 3\% (1 of 35) in mutant mice. C, IR microscopy image of a paired patch-clamp recording from an interneuron (left) and pyramidal neuron (right). Note the characteristic apical dendrite of the pyramidal neuron. D, Reciprocal synaptic connections between a non-FS interneuron (IN) and a pyramidal neuron (PC). The top trace illustrates the presynaptic stimulation pattern and the bottom traces show the respective synaptic responses in both directions. $+\mathrm{m}, T R \alpha 1+/ m$.
GABAergic interneurons, the number of CR-IR cells is increased, the development is mediated by a specific TR isoform, and most importantly, the misdevelopment correlates with distinct functional defects. In contrast to this, the cerebellum exhibited a general delay in the development of markers for GABAergic cells. This is in accordance with the retardation in postnatal maturation we described earlier (Tinnikov et al., 2002) and with the delay in the development of external granular layer cells of the cerebellum (Venero et al., 2005). As elaborated below, the defects in development of specific subtypes of GABAergic interneurons may underlie, when combined with delay in cortical layering and retarded cerebellar maturation, the complex dysfunctions revealed by, for example, the beam walk test and footprint analysis.

Maternal hypothyroidism in the rat causes a temporal delay in the postnatal development of radial glia leading to a reduced number of neurons in layers IV and $\mathrm{V}$ but an increased number in layer VI (Lavado-Autric et al., 2003; Auso et al., 2004; Martinez-Galan et al., 2004). It is likely that the receptor-mediated hypothyroidism of the $T R \alpha 1+/ m$ mice also causes aberrancies in neocortical layering, a hypothesis supported by the decreased thickness of layers II-III observed by the CB immunostaining at P14. A combination of aberrant cortical layering and the mistiming of PV-IR cells may exacerbate effects of an altered connectivity. PV-IR cells could therefore enter the neocortex at a temporally inadequate developmental stage, resulting in persisting defects in PVinterneuron cell identity, connectivity, and tissue architecture.

Adult $T R \alpha 1+/ m$ mice have a reduced mone. The misdevelopment of the PV-IR cells may therefore be caused by a late birth of the corresponding precursor cells, a retarded differentiation program, or an impaired migration of the maturing cells from the MGE to the neocortex.

The discovery that the development of PV-IR was partially rescued by additional TR $\beta$ deletion and that no further improvements could be seen with high maternal TH suggest that the improved performance in the hanging wire test is the consequence of one or more developmental events occurring over an expanded time period. However, the temporal development of PV cells correlates strongly with the rescue of the locomotion phenotype as a whole in both $T R \alpha 1+/ m \beta-/-$ with normal maternal TH and TR $\alpha 1+/ m \beta-/-$ mice with high maternal TH. This suggests that the aberrant development of cortical PV-IR interneurons is an important component of the locomotor dysfunctions observed in the TR $\alpha 1+/ m$ mice.

A previous study on rats that were rendered hypothyroid from E6 until P30 (Gilbert et al., 2007) showed that normal TH levels from birth increased the number of PV-IR cells in the neocortex. Our results demonstrate a critical specificity: the delay seen in $T R \alpha 1+/ m$ mice is highly exclusive for the PV-subtype of number of PV-IR terminals in the hippocampus (Venero et al., 2005), and hypothyroidism in the developing rat causes similar effects in the somatosensory cortex (Gilbert et al., 2007). Importantly, the present network recordings showed that the mutant mice had a lower frequency of gamma oscillations in the hippocampus. Inhibitory interneurons and specifically basket cells, which inhibit excitatory neurons and are FS PV-IR cells, are central for setting oscillation frequency. The reduced frequency of rhythmic network activity in the mutants can therefore be explained by the lower number of FS interneurons (Cobb et al., 1995; Fisahn et al., 1998). Patch-clamp recordings in the neocortex confirmed that this was indeed the case. Furthermore, the non-FS interneurons had intact connections with pyramidal neurons, showing that the disturbances are specific to the FS cells. The electrophysiological data thus verifies that the insults to the GABAergic system, as seen by immunohistochemical staining, result in severe functional defects in the cortices of the mutant mice. The increase in CR-IR cells demonstrates that the mistimed development of the GABAergic system has consequences that persist until adulthood, and indicates that it is accompanied by abnormalities also in tissue architecture and network properties. 
A

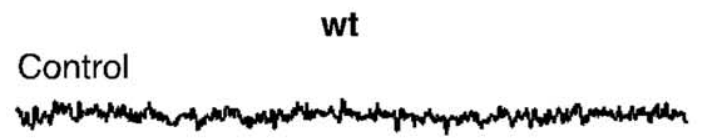

+100 nM Kainate

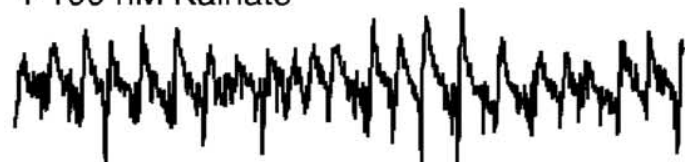

$100 \mu \mathrm{V}$

$200 \mathrm{~ms}$

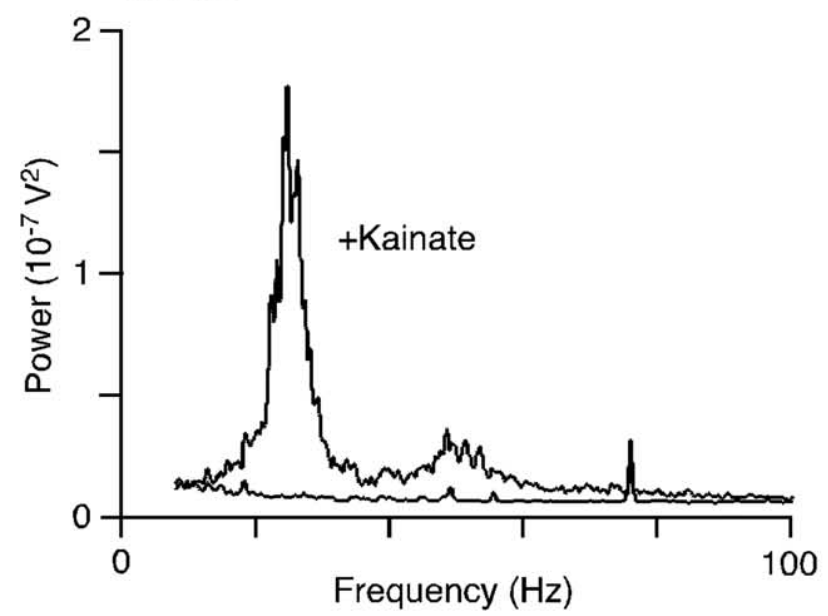

B

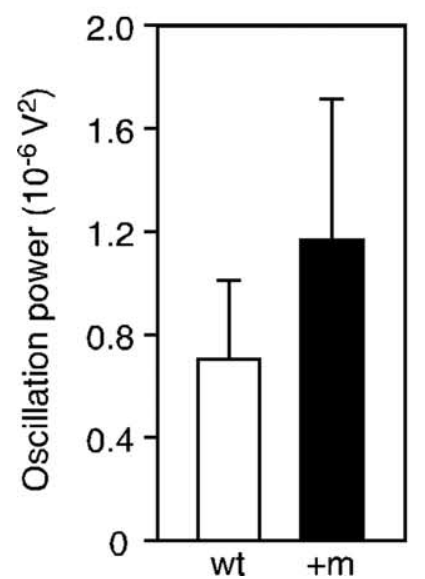

C

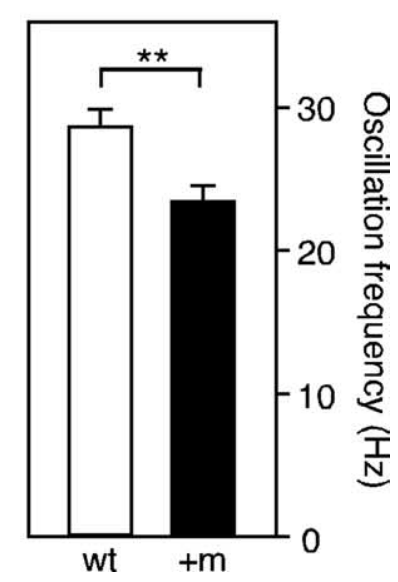

Figure 8. Lower frequency of gamma oscillations. $A$, Example of network activity recorded under control conditions and after application of $100 \mathrm{~nm}$ kainate (top two traces). Below is a spectral analysis of the rhythmic activity in the gamma frequency range (fast Fourier transform) under control conditions and in response to kainate. $\boldsymbol{B}$, No difference in the power of kainateinduced gamma oscillations in wt and mutant preparations. $\boldsymbol{C}$, Lower frequency of kainateinduced gamma oscillations in the mutant preparations compared with wt control. Data are presented as mean $\pm \mathrm{SEM},{ }^{* *} p<0.01$ (Student's $t$ test). $+\mathrm{m}, \mathrm{TR} \alpha 1+/ m$.

\section{Implications for human brain development}

The need for TH in the development of motor skills is well known because of the symptoms seen in individuals suffering from endemic cretinism caused by iodine deficiency during pregnancy (Delange, 1996; DeLong, 1996). Furthermore, previous studies have emphasized the importance of appropriate thyroid hormone levels during pregnancy for correct brain development
(Morreale de Escobar et al., 2004). That an unliganded TR $\alpha 1$ has a more deleterious effect on brain development than the absence of the receptor is amply shown by our demonstration that the neurological dysfunctions displayed by the $T R \alpha 1+/ m$ mice are more severe than those reported for TR knock-out mice (Gauthier et al., 1999; Göthe et al., 1999; Venero et al., 2005). The neuromuscular features of the $T R \alpha 1+/ m$ mice show a striking resemblance with those described for neurological cretins. Similar to these patients, the mutant mice have impaired coordination and balance, walk with everted hind paws and are spastic, and in neither instance can the impairments be fully reversed at later developmental stages.

\section{References}

Alcantara S, Ferrer I, Soriano E (1993) Postnatal development of parvalbumin and calbindin D28K immunoreactivities in the cerebral cortex of the rat. Anat Embryol (Berl) 188:63-73.

Auso E, Lavado-Autric R, Cuevas E, Del Rey FE, Morreale De Escobar G, Berbel P (2004) A moderate and transient deficiency of maternal thyroid function at the beginning of fetal neocorticogenesis alters neuronal migration. Endocrinology 145:4037-4047.

Berbel P, Marco P, Cerezo JR, DeFelipe J (1996) Distribution of parvalbumin immunoreactivity in the neocortex of hypothyroid adult rats. Neurosci Lett 204:65-68.

Bernal J, Guadano-Ferraz A, Morte B (2003) Perspectives in the study of thyroid hormone action on brain development and function. Thyroid 13:1005-1012.

Carter RJ, Morton AJ, Dunnett SB (2001) Motor coordination and balance in rodents. In: Current protocols in neuroscience (Crawley JN, Gerfen CR, Rogawski MA, Sibley DR, Skolnick P, Wray S, eds), pp 8.12.1-8.12.14. New York: Wiley.

Cobb SR, Buhl EH, Halasy K, Paulsen O, Somogyi P (1995) Synchronization of neuronal activity in hippocampus by individual GABAergic interneurons. Nature 378:75-78.

Cobos I, Calcagnotto ME, Vilaythong AJ, Thwin MT, Noebels JL, Baraban SC, Rubenstein JL (2005) Mice lacking Dlxl show subtype-specific loss of interneurons, reduced inhibition and epilepsy. Nat Neurosci 8:1059-1068.

Delange FM (1996) Endemic cretinism. In: Werner and Ingbar's the thyroid, Ed 7 (Braverman LE, Utiger RD, eds), pp 756-767. Philadelphia: Lippincott-Raven.

DeLong GR (1996) The neuromuscular system and brain in hypothyroidism. In: Werner and Ingbar's the thyroid, Ed 7 (Braverman LE, Utoiger RD, eds), pp 826-835. Philadelphia: Lippincott-Raven.

Escobar-Morreale HF, del Rey FE, Obregon MJ, de Escobar GM (1996) Only the combined treatment with thyroxine and triiodothyronine ensures euthyroidism in all tissues of the thyroidectomized rat. Endocrinology 137:2490-2502.

Fisahn A, Pike FG, Buhl EH, Paulsen O (1998) Cholinergic induction of network oscillations at $40 \mathrm{~Hz}$ in the hippocampus in vitro. Nature 394:186-189.

Forrest D, Erway LC, Ng L, Altschuler R, Curran T (1996) Thyroid hormone receptor beta is essential for development of auditory function. Nat Genet 13:354-357.

Gauthier K, Chassande O, Plateroti M, Roux JP, Legrand C, Pain B, Rousset B, Weiss R, Trouillas J, Samarut J (1999) Different functions for the thyroid hormone receptors TRalpha and TRbeta in the control of thyroid hormone production and post-natal development. EMBO J 18:623-631.

Gilbert ME, Sui L, Walker MJ, Anderson W, Thomas S, Smoller SN, Schon JP, Phani S, Goodman JH (2007) Thyroid hormone insufficiency during brain development reduces parvalbumin immunoreactivity and inhibitory function in the hippocampus. Endocrinology 148:92-102.

Göthe S, Wang Z, Ng L, Kindblom JM, Barros AC, Ohlsson C, Vennstrom B, Forrest D (1999) Mice devoid of all known thyroid hormone receptors are viable but exhibit disorders of the pituitary-thyroid axis, growth, and bone maturation. Genes Dev 13:1329-1341.

Guadano-Ferraz A, Benavides-Piccione R, Venero C, Lancha C, Vennstrom B, Sandi C, DeFelipe J, Bernal J (2003) Lack of thyroid hormone receptor alphal is associated with selective alterations in behavior and hippocampal circuits. Mol Psychiatry 8:30-38.

Hatcher JP, Jones DN, Rogers DC, Hatcher PD, Reavill C, Hagan JJ, Hunter 
AJ (2001) Development of SHIRPA to characterise the phenotype of gene-targeted mice. Behav Brain Res 125:43-47.

Hof PR, Glezer II, Conde F, Flagg RA, Rubin MB, Nimchinsky EA, Vogt Weisenhorn DM (1999) Cellular distribution of the calcium-binding proteins parvalbumin, calbindin, and calretinin in the neocortex of mammals: phylogenetic and developmental patterns. J Chem Neuroanat 16:77-116.

Johansson C, Lannergren J, Lunde PK, Vennstrom B, Thoren P, Westerblad $\mathrm{H}$ (2000) Isometric force and endurance in soleus muscle of thyroid hormone receptor-alpha(1)- or -beta-deficient mice. Am J Physiol Regul Integr Comp Physiol 278:R598-R603.

Kawaguchi Y, Kubota Y (1997) GABAergic cell subtypes and their synaptic connections in rat frontal cortex. Cereb Cortex 7:476-486.

Lavado-Autric R, Auso E, Garcia-Velasco JV, Arufe Mdel C, Escobar del Rey F, Berbel P, Morreale de Escobar G (2003) Early maternal hypothyroxinemia alters histogenesis and cerebral cortex cytoarchitecture of the progeny. J Clin Invest 111:1073-1082.

Marin O, Rubenstein JL (2003) Cell migration in the forebrain. Annu Rev Neurosci 26:441-483.

Markram H, Toledo-Rodriguez M, Wang Y, Gupta A, Silberberg G, Wu C (2004) Interneurons of the neocortical inhibitory system. Nat Rev Neurosci 5:793-807.

Marsh-Armstrong N, Cai L, Brown DD (2004) Thyroid hormone controls the development of connections between the spinal cord and limbs during Xenopus laevis metamorphosis. Proc Natl Acad Sci USA 101:165-170.

Martinez-Galan JR, Escobar del Rey F, Morreale de Escobar G, Santacana M, Ruiz-Marcos A (2004) Hypothyroidism alters the development of radial glial cells in the term fetal and postnatal neocortex of the rat. Brain Res Dev Brain Res 153:109-114.

Morreale de Escobar G, Obregon MJ, Escobar del Rey F (2004) Role of thyroid hormone during early brain development. Eur J Endocrinol 151 [Suppl 3]:U25-U37.
Nadarajah B, Parnavelas JG (2002) Modes of neuronal migration in the developing cerebral cortex. Nat Rev Neurosci 3:423-432.

Paxinos G, Franklin KB (2004) The mouse brain in stereotaxic coordinates, Ed 2. San Diego: Elsevier Academic.

Rogers DC, Fisher EM, Brown SD, Peters J, Hunter AJ, Martin JE (1997) Behavioral and functional analysis of mouse phenotype: SHIRPA, a proposed protocol for comprehensive phenotype assessment. Mamm Genome 8:711-713.

Rogister B, Ben-Hur T, Dubois-Dalcq M (1999) From neural stem cells to myelinating oligodendrocytes. Mol Cell Neurosci 14:287-300.

Schwartz HL, Strait KA, Ling NC, Oppenheimer JH (1992) Quantitation of rat tissue thyroid hormone binding receptor isoforms by immunoprecipitation of nuclear triiodothyronine binding capacity. J Biol Chem 267:11794-11799.

Silberberg G, Markram H (2007) Disynaptic inhibition between neocortical pyramidal cells mediated by Martinotti cells. Neuron 53:735-746.

Tinnikov A, Nordstrom K, Thoren P, Kindblom JM, Malin S, Rozell B, Adams M, Rajanayagam O, Pettersson S, Ohlsson C, Chatterjee K, Vennstrom B (2002) Retardation of post-natal development caused by a negatively acting thyroid hormone receptor alpha1. EMBO J 21:5079-5087.

Venero C, Guadano-Ferraz A, Herrero AI, Nordstrom K, Manzano J, de Escobar GM, Bernal J, Vennstrom B (2005) Anxiety, memory impairment, and locomotor dysfunction caused by a mutant thyroid hormone receptor alphal can be ameliorated by T3 treatment. Genes Dev 19:2152-2163.

West MJ, Slomianka L, Gundersen HJ (1991) Unbiased stereological estimation of the total number of neurons in the subdivisions of the rat hippocampus using the optical fractionator. Anat Rec 231:482-497.

Yu F, Gothe S, Wikstrom L, Forrest D, Vennstrom B, Larsson L (2000) Effects of thyroid hormone receptor gene disruption on myosin isoform expression in mouse skeletal muscles. Am J Physiol Regul Integr Comp Physiol 278:R1545-R1554. 